Vol. 8 (1) 5 - 9

\title{
Distribution and Statistical Analysis of Bacteria in Lake Alau in the Arid Northern Nigeria
}

\author{
${ }^{1}$ IDAKWO, P Y; ${ }^{* 2}$ ABU, G O \\ ${ }^{1}$ Department of Food Science, Ramat Polytechnic, P.M.B. 1070, Maiduguri, Borno State, Nigeria \\ ${ }^{2}$ Environmental and Industrial Microbiology Unit, Department of Microbiology, University of Port Harcourt, P.M.B. 5323, Port Harcourt
}

\begin{abstract}
The direct microscopic count using bright field illumination was subjected to a statistical comparison with four different microbial cell viability procedures viz., pour plate, spread plate, most probable number (MPN) and membrane filtration (MF) for the analysis of the distribution of bacteria in water samples from Lake Alau Dam in the arid Northern Nigeria. A total of 27 samples were collected from three locations of the dam site and analysed. The total coliform represented $32 \%$ of the 22 isolates and of this $10 \%$ represented the fecal coliform bacteria. The fecal coliform level of $6.0 \times 10^{2}$ to $8.8 \times 10^{2} / 100 \mathrm{ml}$ placed lake Alau Dam water samples in the EEC Grade A2 and thus, the water is recommended for further treatments before it can be distributed to municipalities for domestic use. Statistical analysis using one-way analysis of variance (ANOVA) showed significant differences in counts between three locations, based on the direct microscopic counts. There were no significant differences in counts between locations using the four cultural methods. There was an honestly significant difference (hsd, $5 \%$ level, Tukeys test) between the direct microscopic counts and the four cultural methods, but there was not honestly significant difference (hsd, $5 \%$ level) between the four cultural methods. It is concluded that in the absence of more sophisticated procedures, the four cultural methods together with the direct bright field microscopic count procedure served to establish a good measure of the microbiological quality of the Lake Alau water, this is strengthened by the statistical correlations. @JASEM
\end{abstract}

The drinking water of most countries, communities and municipalities is obtained from surface sources such as rivers, streams and lakes (Diamant, 1980). Such natural water supplies particularly streams and rivers are likely to be polluted with domestic, industrial and agricultural wastes (Diamant, 1980; Wong, 1979). In Maiduguri, the Borno State Capital in the arid Northern Nigeria, drinking water is obtained from boreholes. The annual rainfall ranges from $500 \mathrm{~mm}$ to $1000 \mathrm{~mm}$ and relative humidity is about $49 \%$, with evaporation of $2934 \mathrm{~mm}$ per year and temperature range of 38 to $40^{\circ} \mathrm{C}$ during the hottest months of March and April, under shade (NYSC, 1990/91 report). These factors together with persistent draught, very short rainfall period and desertification had made the water table very difficult to reach. In addition, the cost of drilling new boreholes and maintenance of the old ones had been on the increase. The Borno State Government in an effort to solve the water problem in Maiduguri had sought the assistance of the World Bank and this led to the initiation of a water project in 1986 to channel water from Lake Alau to treatment plants located in Maiduguri for purification and subsequent distribution to the metropolis. The assessment of potability generally is based on knowledge of the sanitary condition of the supply as determined by bacteriological monitoring. Water quality monitoring is based on the detection of coliform bacteria and the specific indicator of human faecal contamination, Escherichia coli (Atlas, 1991; Bonde, 1977). The traditional methods for detecting coliform bacteria rely on culturing on a medium that selectively permits the growth of Gram negative bacteria and differentially detects lactose utilizing bacteria e.g., using M-Endo, E.M.B. or BGLB media (Mahbubani et al., 1990). There are several problems with the viable culture methods used for routine monitoring of the bacteriological quality of water supplies. These include maintaining the viability of bacteria between the time of collection and enumeration, lack of growth of viable but non-culturable bacteria (Spence et al., 1974), due to stress, induced by chemicals in the water, time required for detection and confirmation of enteric bacteria (which can be days) and lack of specificity for detection of true fecal coliforms. Rapid and sensitive, non-culture, genetically based procedures for the environmental detection of coliforms i.e., using the polymerase chain reaction (PCR) and detection of the amplified DNA with gene probes had been developed (Atlas, 1991; Mahbubani et al., 1990). Tests based on detection of B-D glucuronidase, such as the colilert test (Access Analytical system, Brandord Conn. USA), have been suggested as alternate approaches for detecting coliforms (Edberg and Kontnick, 1986),

\footnotetext{
* Corresponding author: E-mail:
} 
but detection of such enzymatic activities still requires culturing the bacteria. It has been reported (Chang et al., 1989) that use of $\beta$-D- glucuronidase activity may fail to detect a significant proportion (circa 30\%) of faecal coliform bacteria in some cases because of occurrences of high incidence of $\beta$-Dglucuronidase negative $E$. coli. Alternatively, standard cultural methods can be used if subjected to proper statistical analysis.

The objective of this study therefore was to analyse, statistically, the data obtained using one direct microscopic method with data from four cultural methods in the enumeration of heterotrophic bacteria in a lake situated in an arid zone of Northern Nigeria. The goal was to establish the bacteriological quality of the water with a high degree of confidence that is protective of this community, like many others in developing countries.

\section{MATERIALS AND METHODS}

Sampling Sites

Lake Alau is located on latitude $11^{\circ} 41 \mathrm{~N}$ and longitude $13^{\circ}, 16 \mathrm{E}$ on the South Eastern (SE) part of Maiduguri, the Borno State Capital Nigeria. There are no permanent human settlements around the lake except the tents of migrant fishermen around the bank of the lake. For the purpose of this study, the lake was divided into three sampling points based on the physical relief of the lake and the density of human activities around it.

\section{Collection and Processing of Samples}

A total of 27 water samples were collected from the sampling points. At each point, samples were collected from the surface $(0-0.25 \mathrm{~m})$, middle $(2.5 \mathrm{~m})$ and bottom water $(5 \mathrm{~m})$. A total of 9 samples were collected from each point. Adequate precautions were taken to avoid contamination of samples. The samples from the middle and bottom were collected using a device similar to the Niskin sampler (Niskin, 1962). In each case pre-sterilized, 200ml plastic bottles were used and a space of about $1.5 \mathrm{~cm}$ was left in each bottle to facilitate mixing. Sample collection spanned from March to August. In the arid Northern Nigeria, this period spans over one third of the dry season (i.e. October to June) and two thirds of the rainy season (i.e. June to September).

For the direct microscopic counts the samples were first diluted and the cells fixed using formaldehyde. The cells were counted under brightfield illumination using the improved Neubauer Hemocytometer. Total viable counts (TVC) were determined by pour plate, spread plate, membrane filtration (MF) and the 5 tube most probable number (MPN) procedures (Greenberg, 1985). The MF method was extended to include determination of the total coliform and fecal coliform counts. Positive tubes from the lauryl tryptose broth of the MPN procedure were examined for the presence of Escherichia coli by testing the culture for the ability to grow in Brilliant green lactose bile broth medium at $44.5^{\circ} \mathrm{C}$ (Greenberg, 1985). The biochemical oxygen demand (BOD) which is indicative of the level of biodegradable organic matter (Brower and Zar, 1979) was performed on the lake Alau water samples.

\section{Statistical Analysis}

In order to determine statistical relationships among the bacterial populations recovered at the three locations, a one way analysis of variance (ANOVA) test was used (Spence et al., 1974). A similar analysis was applied to test the relationships of the five methods used for the enumeration. Where significant differences were observed, the data were further subjected to Tukeys test (Spence et al., 1974) which determines how honestly significant (hs) the observed differences are. Thus, this test is usually performed only if the $\mathrm{F}$ value obtained in an analysis of variance indicates a significant difference. The Tukeys test is described by the equation:

$$
H_{s d}=q_{a} \sqrt{\frac{M S_{w g}}{N_{g}}}
$$

where MSwg is the within group mean square calculated in the analysis of variance; $\mathrm{Ng}$ is the number of cases in each group; the value $q_{\alpha}$ also called studentised range statistics is obtained from $\mathrm{q}_{\alpha}$ tables (Spence et al., 1974).

\section{Correlations to be established}

The following correlations were sought viz., statistical conclusions relating the bacterial populations at the three sampling locations, both inter-location and intra-location on the one hand and statistical conclusions relating the five methods used on the other. Correlations arrived at would strengthen or weaken the choice and application of any of the methods for monitoring of the water quality of Lake Alau.

\section{RESULTS}

The bacterial populations of Lake Alau using the direct microscopic, and four cultural methods are shown in Table 1 . The five methods gave a geometric mean of $4.0 \times 10^{1}-2.3 \times 10^{6} / 100 \mathrm{ml}$. The results of the analysis of variance (ANOVA) performed to confirm the consistency of the counts at the different locations are shown in Table 2 . 
Table 1: Total heterotrophic bacterial population of lake Alau (geometric mean of 9 replicates)

\begin{tabular}{|c|c|c|c|c|c|}
\hline $\begin{array}{l}\text { Sa } \\
\text { mp } \\
\text { le }\end{array}$ & $\begin{array}{l}\text { Direc } \\
\mathrm{t} \\
\text { Count } \\
\text { (Cells } \\
/ 100 \\
\mathrm{ml})\end{array}$ & $\begin{array}{l}\text { Pour } \\
\text { Plate } \\
\text { (cfu/ } \\
100 \\
\mathrm{ml} \text { ) }\end{array}$ & $\begin{array}{l}\begin{array}{l}\text { Spre } \\
\text { ad }\end{array} \\
\text { Plate } \\
\text { (cfu/ } \\
100 \\
\mathrm{ml})\end{array}$ & $\begin{array}{l}\text { M } \\
\text { PN } \\
\text { per } \\
10 \\
0 \mathrm{~m} \\
\mathrm{l}\end{array}$ & $\begin{array}{l}M \\
F \\
\text { per } \\
10 \\
0 \mathrm{~m} \\
\mathrm{l}\end{array}$ \\
\hline $\begin{array}{l}\text { A } \\
\text { L } \\
\text { DS }\end{array}$ & $\begin{array}{l}2.3 \times 1 \\
0^{6}\end{array}$ & $\begin{array}{l}1.9 \mathrm{x} \\
10^{5}\end{array}$ & $\begin{array}{l}2.1 \mathrm{x} \\
10^{5}\end{array}$ & $\begin{array}{l}5.5 \\
\times 1 \\
0^{1}\end{array}$ & $\begin{array}{l}3.1 \\
\mathrm{x} 1 \\
0^{5}\end{array}$ \\
\hline $\begin{array}{l}\text { A } \\
\mathrm{L}\end{array}$ & $\begin{array}{l}1.2 \times 1 \\
0^{6}\end{array}$ & $\begin{array}{l}1.8 \mathrm{x} \\
10^{5}\end{array}$ & $\begin{array}{l}1.84 \\
\times 10^{5}\end{array}$ & $\begin{array}{l}5.1 \\
\mathrm{x} 1\end{array}$ & $\begin{array}{l}2.5 \\
\mathrm{x} 1\end{array}$ \\
\hline $\begin{array}{l}\mathrm{D} \\
\mathrm{M}\end{array}$ & $\begin{array}{l}6.7 \times 1 \\
0^{5}\end{array}$ & $\begin{array}{l}9.3 x \\
10^{4}\end{array}$ & $\begin{array}{l}1.4 \mathrm{x} \\
10^{5}\end{array}$ & $0^{1}$ & $0^{5}$ \\
\hline $\begin{array}{l}\text { A } \\
\text { L } \\
\text { D } \\
\text { B }\end{array}$ & & & & $\begin{array}{l}4.0 \\
\mathrm{x} 1 \\
0^{1}\end{array}$ & $\begin{array}{l}2.4 \\
\mathrm{x} 1 \\
0^{5}\end{array}$ \\
\hline
\end{tabular}

The analysis showed significant difference at the $5 \%$ level of confidence. The five methods were also subjected to analysis of variance to determine if any correlation existed between them. The results are shown in Table 3 and indicate significant difference between the methods for all the locations. The results obtained with the endo broth (Table 4) serve to establish bacteriological quality of the samples. The biochemical oxygen demand (BOD) test for the Lake Alau water gave values ranging between $0.32 \mathrm{mg} / \mathrm{l}$ and $0.45 \mathrm{mg} / \mathrm{l}$, indicating that the lake water is greatly impoverished in biodegradable organic nutrients.

Table 2: Summary of Statistical Analysis for the Comparison of data from the threeSampling Locations using the five methods.

\begin{tabular}{|c|c|c|c|c|c|c|c|}
\hline Methods & $\begin{array}{l}\text { Sources of } \\
\text { Variations }\end{array}$ & SS & $\mathrm{df}$ & MS & $\begin{array}{l}\text { Tabulated } \\
* \text { F value }\end{array}$ & $\begin{array}{l}\text { Calculated } \\
\text { F value }\end{array}$ & $\begin{array}{c}\text { Statistical } \\
\text { conclusion }\end{array}$ \\
\hline \multirow{3}{*}{$\begin{array}{l}\text { Direct } \\
\text { Count }\end{array}$} & $\mathrm{BL}$ & $1.21 \times 10^{13}$ & 2 & $6.03 \times 10^{12}$ & 3.40 & 16.1 & S \\
\hline & WL & $9.00 \times 10^{11}$ & 24 & $3.8 \times 10^{11}$ & & & \\
\hline & Total & $2.11 \times 10^{13}$ & 26 & & & & \\
\hline \multirow{3}{*}{$\begin{array}{l}\text { Pour } \\
\text { Plate }\end{array}$} & BL & $5.40 \times 10^{10}$ & 2 & $2.7 \times 10^{10}$ & 3.40 & 2.60 & NS \\
\hline & WL & $3.00 \times 10^{11}$ & 24 & $1.04 \times 10^{10}$ & & & \\
\hline & Total & $3.00 \times 10^{11}$ & 26 & & & & \\
\hline \multirow{3}{*}{$\begin{array}{l}\text { Spread } \\
\text { Plate }\end{array}$} & BL & $4.35 \times 10^{12}$ & 2 & $8.56 \times 10^{9}$ & 3.40 & 0.47 & NS \\
\hline & WL & $4.35 \times 10^{12}$ & 24 & $1.81 \times 10^{10}$ & & & \\
\hline & Total & $4.53 \times 10^{12}$ & 26 & & & & \\
\hline \multirow[t]{3}{*}{ MPN } & BL & $1.23 \times 10^{3}$ & 2 & $6.16 \times 10^{2}$ & 3.40 & 0.46 & NS \\
\hline & WL & 3..20xx10 $0^{4}$ & 24 & $1.81 \times 10^{10}$ & & & \\
\hline & Total & $3.32 \times 10^{4}$ & 26 & & & & \\
\hline \multirow[t]{3}{*}{ MF } & BL & $2.50 \times 10^{10}$ & 2 & $1.23 \times 10^{10}$ & 3.40 & 3.12 & NS \\
\hline & WL & $9.50 \times 10^{10}$ & 24 & $3.95 \times 10^{9}$ & & & \\
\hline & Total & $1.20 \times 10^{11}$ & 26 & & & & \\
\hline
\end{tabular}

${ }^{*} \mathrm{~F}^{\mathrm{V} 1} \mathrm{~V} 2$ (0.05), $\mathrm{S}=$ significant, $\mathrm{NS}=$ Not Significant, $\mathrm{SS}=$ sum of squares, MS = mean square $\mathrm{df}=$ degrees of freedom, $\mathrm{BL}$ and $\mathrm{WL}$ are $=$ Between and within limits 
Table 3: Summary of Statistical Analysis for the Comparison of the enumeration methods

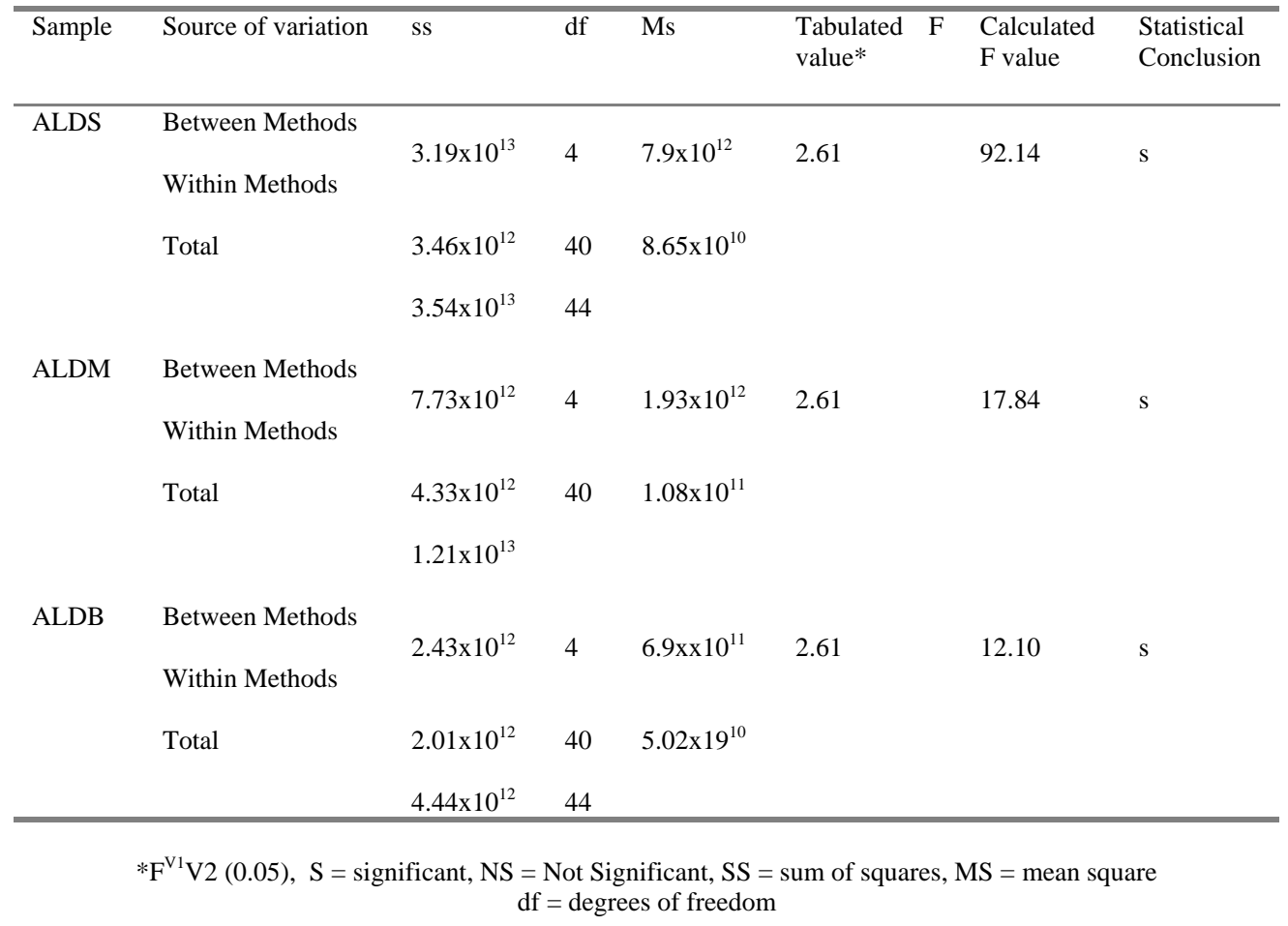

\section{DISCUSSION}

Generally organic carbon levels of less than $1 \mathrm{mg} / \mathrm{l}$ are considered to be on the low side for aquatic ecosystems. With $\mathrm{BOD}_{5}$ values of between 0.32 to $0.45 \mathrm{mg} / \mathrm{l}$ the Lake Alau water can be considered as being low in biodegradable organic nutrients. The arid nature of the environment may partly account for this. Bacterial numbers in water bodies, especially the neuston or epilimnion where there is usually an enrichment of nutrients, can be in excess of $10^{5}$ cells $/ \mathrm{ml}$. The bacterial load for Lake Alau shown in Table 1 is on the low to moderate side with the highest count of $2.3 \times 10^{4} / \mathrm{ml}$ obtained with the direct count procedure. This may be explained partly on the basis of the low biodegradable organic carbon level. There is an apparent decrease in the bacterial count from the surface to the bottom water samples, suggesting that the surface layers may be more enriched in nutrients thus supporting more bacterial populations. Analysis of variance showed a significant difference for the counts at the three locations using the microscopic direct count procedure. The observed difference on subjection to Tukey's test showed the difference to be honestly significant. There was no significant difference between the locations when the four cultural methods were used. The four cultural methods were not subjected to the Tukey's test, as there were no significant differences observed in the first instance. Thus, from this study, the probability of finding a significant difference using the direct microscopic
Table 4: Total and fecal coliform counts of Lake Alau Dam Site

\begin{tabular}{lll}
\hline Samples & \multicolumn{2}{l}{ Total Coliforms } \\
& $\begin{array}{l}\text { at } 37^{\circ} \mathrm{C} \text { Per } \\
100 \mathrm{ml}\end{array}$ & $\begin{array}{l}\text { Faecal Coliforms } \\
\text { at } 44.5^{\circ} \mathrm{C} \text { Per } 100 \mathrm{ml} .\end{array}$ \\
\hline ALDS & $7.3 \times 10^{3}$ & $8.8 \times 10^{1}$ \\
ALDM & $6.9 \times 10^{3}$ & $6.0 \times 10^{1}$ \\
ALDB & $8.0 \times 10^{3}$ & $7.9 \times 10^{1}$ \\
\hline
\end{tabular}

procedure for the counts at the locations by chance at any given level of significance increased with different locations in the order ALDB $<$ ALDM $<$ ALDS i.e., $\left(7.7 \mathrm{X} 10^{5}\right)<\left(8.6 \mathrm{X} 10^{5}\right)<\left(1.63 \mathrm{X} 10^{6}\right)$ cells/ $\left./ 100 \mathrm{ml}\right)$. It is often difficult to distinguish bacteria from non living particulate material in natural water samples (Bowden, 1977). Other authors (Wiebe and Pomeroy, 1972) have discussed this problem with reference to phase contrast microscopy. The use of immunological methods, such as fluorescent antibodies is a good alternative but the detection limit of the microscope will still be the restricting factor (Notermans and Warnars, 1991). In this study, shape and texture were used as two important criteria to identify bacteria as did other workers (Wiebe and Pomeroy, 1972). The particles that were obviously bacteria had round shapes and smooth surface texture. Non living particles comprised small fragments of plant and animal material, suspended 
sediment and other irregularly shaped particles. Bacteria were seldom seen attached to particles. The low count obtained with the membrane filtration procedure also supports this observation, and is noteworthy. Subjectivity is a noted factor in the direct microscopic count procedure (Bowden, 1977), yet, this method could be used when a rapid estimate of microbial population is required considering the variations within a population of aquatic bacteria, and is sufficient to make meaningful comparisons between techniques and populations. The five methods were subjected to analysis of variance and results indicated significant differences in the methods at the three locations as seen in Table 3. These were further subjected to Tukey's test and it was observed that only a difference between a pair of means involving the Direct Microscopic count exceeded the critical value of $3.02 \times 10^{5}$ cells $/ 100 \mathrm{ml}$ and thus showed honestly significant difference. Differences in means between the four cultural methods were less than the critical value thus, suggesting the four cultural methods were not honestly significantly different from one another in their bacterial counts. The total and fecal coliform counts of $6.9 \times 10^{5}$ to $8.0 \times 10^{5} / 100 \mathrm{ml}$ and $6.0 \times 10^{2}$ to $8.8 \times 10^{2}$ respectively confirmed Lake Alau water as being contaminated with fecal matter, placing the Lake water in the contamination grade A2 of the EEC guidelines (Anon, 1975) and thus, requires such treatment as pre-chlorination, coagulation, flocculation, rapid filtration and final chlorination before it can be distributed for domestic use. Statistical analyses are useful in establishing confidence in a given procedure and methodology. This is because often times a sizeable amount of data is involved. This helps in eliminating chance occurrences. The statistical conclusions arrived at in this study can serve as a good reference for water quality issues for a less developed society.

\section{REFERENCES}

Anon (1975) Council Directive Concerning the Quality required of surface water intended for Abstraction of Drinking Water in Member States R/848/75 (ENV38).Brussels: The European Economic Community.

Atlas, R M. (1991) Environmental Applications of the Polymerase Chain Reaction. ASM News 57:632.

Bonde, G J (1977) Bacteria Indicators of water pollution. Adv. Aquatic microbial, 1:273-364.
Bowden, W.B. (1977) Comparison of two direct count techniques for enumerating equatic

Bacteria. Appl. Environ, Microbiol. 13:1229-1232.

Brower, J.E. and Zar, J.H. (i979). Field and laboratory methods for general ecology. E.C. Brown Company (Pub.) 2 ${ }^{\text {nd }}$ Ed. P. 194.

Chang, GW , Brill J; Lum, R. (1989) Proportion of $\beta$ D-glucuronidase negative Escherichia coli in human faecal samples. Appl. Environ. Microbiol. 55:335-339.

Diamant, B.Z. (1980) Environment Health Impacts of water use in Africa. Proc. Water Techn. 13:171178.

Edberg, S. C. and Kontnick, C.M. (1986) Comparison of $\beta$-glucuronidase based substrate systems for identification of Escherichia coli J. Clin. Microbiol. 24:368-399.

Greenberg, H. (ed) (1985) Standard methods for the Examination of water and waste water. Am. Publ. Hlth. Assoc. Washington, DC.

Mahbubani, M.H., Bej, A.K., Miller, R., Haff, L. Dicesare, I. and Atlas, R.M. (1990). Detection of legionella with polymerase chain reaction and gene probe methods. Mo. Cell. Probes 4:175-187.

Niskin, S. (1962) A water sampler for Microbiological studies. Deep Sea Res. 9:501-503.

Notermans, S. and Warnars, K. (1991) Immunological methods for detection of food borne pathogens and their toxins. Int. J. Food Microbiol. 12:91-102.

N.Y.S.C. (National Youth Service Corp) Handbook (1990/91). Borno State.1990/91 Service year.

Spence, J T; Cotton, J W; Underwood, B J (1974) Elementary Statistics $3^{\text {rd }}$ Edition PrenticeHall Inc. New Jersey.

Wiebe, W J; Pomoeroy, LP (1972) Microorganisms and their association with Aggregates and detritus in the sea: a Microscopic study pp. 325 -342: In U. Malchirri - Santorini and Hopton, J.W. (ed) Detritus and its role in aquatic habitats. Memoria dell’ Institute Italians di idrobiologia Vol. 29.

Wong, MH (1979) Agricultural wastes of fresh water supply in Hong Kong Inc. Prog. Water Tech. 6:121-132. 